\section{Plan for government researchers in Japan to work in industry}

[токуо] Japan's Science and Technology Agency (STA) has asked the government to reduce restrictions on scientists who work at national research institutes as part of its efforts to create a more flexible, open and competitive research environment.

The request, submitted last week to the government's personnel office, asks for 'research bureaucrats' - as researchers at national institutes are called - to be given more freedom to work in different sectors, such as industry and the academic community. At present, such external activities are strictly regulated by civil service law.

The move is in line with the 1996 Basic Law for Science and Technology, which calls for the promotion of collaborative research between industry, government and universities. It also reflects the thrust of last year's administrative reform drive, which called for a substantial shake-up of management styles within nationally run research centres.

The STA also intends to explore the possibility of turning national research institutes into 'independent administrative agencies'.

One of the main reforms being requested by the agency is that researchers be allowed to take lengthy sabbaticals, during which they could take up research different from their normal work, such as projects at profitmaking organisations.

The STA hopes that, by reducing bureaucratic obstacles, researchers at national institutes will be able to experience different research environments and improve their standards by carrying out independent research activities.

At the same time, the agency wants the introduction of a system to assess laboratory technicians to allow them to respond to the rapid diversification of scientific fields. The aim is for technicians to be assessed and classified according to their experience and scientific knowledge. The current system merely distinguishes between 'administrative staff' and 'research staff', placing both in one of the lowest salary categories.

The goal is to increase the number of skilled technicians by making it more attractive for them to work in national research institutes. Such a move would be welcomed by scientists, who have long complained about the shortage of skilled technicians.

The STA is also seeking a revision of researchers' salaries to balance them with those of companies and universities, as part of an effort to attract talented researchers.

Scientists welcome the STA's requests. A survey by the agency last year showed that 67 per cent of researchers at national laboratories wanted more freedom. Asako Saegusa

\title{
Fraud squad files report to prosecutor in Inserm case
}

[PARIS] Legal authorities in France may launch shortly a more far reaching investigation into a controversial affair involving alleged scientific misconduct than the limited inquiry promised by the Ministry of National Education, Research and Technology.

The fraud squad in Rennes this month submitted an 'information file' ('dossier de renseignement') to M. Tremoureux, the public prosecutor of the region, making the case for opening an investigation into allegations of fraud at the Laboratory of Nutrition, Lipoprotein Metabolism and Atheroschlerosis, at the University of Rennes 1.

The laboratory is headed by Bernard Bihain, and is part of Inserm, the national biomedical research agency. The allegations centre on published claims by the laboratory to have identified and cloned the so-called 'lipolysis stimulated receptor', a molecule involved in fat degradation. The work has been patented by Inserm and the French biotechnology company Genset (see Nature 391, 519 \& 825; 1998).

The decision on whether to launch a judicial inquiry is the responsibility of the public prosecutor. But police sources point out that 'whistleblowers' who have already testified in the case have made "clear declarations" alleging scientific fraud - a misdemeanour in France - and related offences.

The sources add that knowingly applying for a patent on the basis of fraudulent claims would also be an offence. Olivier Schnerb, the lawyer representing Bihain, last week refused to comment on the grounds that the investigation was continuing.

Further pressure for a judicial inquiry is likely to come from Jacques Lenfant, the president of the University of Rennes 1, and Jean-Pierre Brun, vice-president for research, who intend to invoke a law that requires civil servants to alert the public prosecutor if in the execution of their duties they become aware of a misdemeanour or crime.

In an outspoken article in Le Monde last week, Lenfant and Brun also challenged the ministry's handling of the affair. They argued that this fell short of Germany's handling of recent allegations of misconduct, where procedures were established to "immediately treat, drastically and with clarity, suspicions of scientific fraud" (see Nature 390, 430; 1997).

The article even alleges that Inserm "has refused a request for scientific clarification... by hiding behind the screen of internal evaluation procedures, which in this case are themselves highly questionable". Ministry officials could not be reached for comment last week.

The allegations of fraud have been described in particular in a report by a fourmember committee of inquiry, chaired by Pierre Corvol, professor of experimental medicine at the Collège de France, in Paris. The committee heard testimony from 24 researchers and technicians who work or have worked in the laboratory.

The Corvol inquiry concluded that the testimonies of seven of these individuals raised doubts about the "validity of certain results published or in the process of publication by the director of the laboratory [Bihain]".

But controversy surrounds the Corvol report. It was not made available to a meeting in November 1997 of the scientific board of Inserm at which Bihain's unit was evaluated.

More extensive investigation called for in the Corvol report was carried out by Bernard Bigot, the then director general of the research ministry. Bigot's report, submitted to the ministry in December, cleared the laboratory of misconduct.

In their article, Lenfant and Brun ask why the minister and his advisers allowed Bigot to "hush up" the Corvol report. Lenfant and Brun describe it as "unacceptable" that the university was not asked to carry out an inquiry, and complain that the university has suffered from "a total absence of information from the ministry".

Daniel Nahon, Bigot's successor at the ministry, announced in May that four international experts had been commissioned to complete a new inquiry within three months (see Nature 393, 203; 1998). But this has done little to dampen suspicions. Many remain concerned that the inquiry will only consider published data, and not hear evidence on the conduct of experiments from the 'whistleblowers'.

Some scientists are critical of the role of the media, including Nature which first brought the affair into the public eye. Alluding to the role of the press, Marc Pescanski, the Inserm representative on the Corvol committee, deplores "the complete destruction of an Inserm unit despite any evidence of wrongdoing, and before any formal accusation has been made".

Claude Griscelli, the director general of Inserm, last week told Nature that the laboratory is to close, as Bihain had asked to be discharged from his duties on "personal grounds". But several scientists nonetheless argue that this should not be used to justify any reduction in efforts to get to the bottom of the affair. 